\title{
Identification and Characterization of $S$-RNases in Tetraploid Sour Cherry (Prunus cerasus)
}

\author{
Hisayo Yamane, ${ }^{1}$ Ryutaro Tao, ${ }^{1}$ and Akira Sugiura \\ Laboratory of Pomology, Graduate School of Agriculture, Kyoto University, Kyoto 606-8502, Japan \\ Nathanael R. Hauck and Amy F. Iezzoni \\ Department of Horticulture, Michigan State University, East Lansing, MI 48824
}

AdDitional INDEX wORDs. gametophytic self-incompatibility, polyploid, RFLP, Rosaceae, $S$-allele

\begin{abstract}
This report demonstrates the presence of $S$-ribonucleases ( $S$-RNases), which are associated with gametophytic self-incompatibility (SI) in Prunus L., in styles of self-incompatible and self-compatible (SC) selections of tetraploid sour cherry (Prunus cerasus L.). Based on self-pollen tube growth in the styles of 13 sour cherry selections, seven selections were SC, while six selections were SI. In the SI selections, the swelling of pollen tube tips, which is typical of SI pollen tube growth in gametophytic SI, was observed. Stylar extracts of these selections were evaluated by two-dimensional polyacrylamide gel electrophoresis. Glycoproteins which had molecular weights and isoelectric points similar to those of $S$-RNases in other Prunus sp. were detected in all selections tested. These proteins had immunological characteristics and $\mathrm{N}$-terminal amino acid sequences consistent with the $S$-RNases in other Prunus sp. Two cDNAs encoding glycoproteins from 'Erdi Botermo' were cloned. One of them had the same nucleotide sequence as that of $S^{4}$-RNase of sweet cherry (Prunus avium L.), while the amino acid sequence from the other cDNA encoded a novel $S$-RNase (named $S^{a}$-RNase in this study). This novel RNase contained two active sites of T2/S type RNases and five regions conserved among other Prunus $S$-RNases. Genomic DNA blot analysis using cDNAs encoding $S$-RNases of sweet cherry as probes indicated that three or four $S$-RNase alleles are present in the genome of each selection regardless of SI. All of the selections tested seemed to have at least one $S$-allele that is also found in sweet cherry. Genetic control of SI/SC in tetraploid sour cherry is discussed based on the results obtained from restriction fragment length polymorphism analysis.
\end{abstract}

Gametophytic self-incompatibility (SI) is a widespread mechanism in flowering plants which prevents self-fertilization and promotes outcrossing (de Nettancourt, 1977). Most rosaceous tree fruit crops exhibit this SI system which is controlled by a single locus $(S$ locus) with multiple alleles (de Nettancourt, 1977). In this system, pollen tube growth is arrested if the pollen tube has a $S$-allele which is in common with the style. Recently, the molecular mechanism of gametophytic SI in Prunus sp. has been studied, and $S$-gene products in pistils of almond [Prunus dulcis (Mill.) D.A. Webb (syn. $P$. amygdalus Batsch) (Tao et al., 1997; Ushijima et al., 1998), apricot $(P$. armeniaca L.) (Burgos et al., 1998), Japanese plum (P. salicina Lindl.) (Yamaneet al., 1999), and sweet cherry (P. avium) (Boskovic and Tobutt, 1996; Tao et al., 1999b) were shown to be $S$-RNases, as is the case with other rosaceous crops, such as apple [Malus sylvestris (L.) Mill. var. domestica (Borkh.) Mansf.] (Broothaerts et al., 1995; Sassa et al., 1994, 1996) and pear (Pyrus L. sp.) (Ishimizu et al., 1996; Sassa et al., 1992, 1996; Tomimoto et al., 1996).

One interesting aspect of gametophytic SI is that it commonly breaks down as a result of polyploidy resulting in self-compatible (SC) individuals. This breakdown of gametophytic SI in polyploid plants with SI diploid relatives has been documented in Lycopersicon Mill. (Chawla et al., 1997; de Nettancourt et al., 1974), Nicotiana L. (Pandy, 1968), Petunia Juss. (Entani et al., 1999; Stout and Chan-

Received for publication 3 Oct. 2000. Accepted for publication 18 June 2001. This work was supported in part by grant in aid 09460018 for scientific research (B) to R. Tao and 4564 for research fellows of the Japanese Society for the Promotion of Science to H. Yamane from the Ministry of Education, Science, Sports, and Culture, Japan. We gratefully acknowledge J. Soejima, K. Tobutt, R.L. Andersen, and C. Choi for providing plant material, H. Sassa for providing antiserum prepared against $S$-RNase of almond, G. Lang and K. Ushijima for critical reviews of this manuscript, and Hitoshi Mori, Nagoya University, for helpful discussion. The cost of publishing this paper was defrayed in part by the payment of page charges. Under postal regulations, this paper therefore must be hereby marked advertisement solely to indicate this fact.

${ }^{1}$ Research fellow of the Japanese Society for the Promotion of Science.

${ }^{2}$ Corresponding author; e-mail rtao@kais.kyoto-u.ac.jp. dler, 1942), Solanum L. (Livermore and Johnstone, 1940), Trifolium L. (Brewbaker, 1954), and Pyrus (Crane and Lewis, 1942). In Prunus, this phenomenon is exhibited in the diploid sweet cherry $(2 \mathrm{n}=2 \mathrm{x}=16)$ and the tetraploid sour cherry $(P$. cerasus $\mathrm{L}$., $2 \mathrm{n}=4 \mathrm{x}$ $=32$ ). Prunus cerasus ( sour cherry) is thought to have resulted from hybridization between sweet cherry and the tetraploid ground cherry ( $P$. fruticos $a$ Pall., $2 \mathrm{n}=4 \mathrm{x}=32$ ) (Brettin et al., 2000; Olden and Nybom, 1968). Sour cherry cultivars are predominately SC, however, SI types have been reported by pollination tests (Lansari and Iezzoni, 1990; Redalen, 1984a, 1984b). In addition, SI sour cherry selections can result from crosses between two SC parents (Lansari and Iezzoni, 1990). In contrast to sweet cherry, inheritance of SI in sour cherry has not been determined and no $S$-allele designations have been proposed. Since sour cherry is a Prunus sp. that has SI individuals, it is likely to possess $S$-alleles encoding pistil $S$-RNases. To date, no studies of $S$-RNases in sour cherry have been reported. In this study, evidence is presented that both SI and SC sour cherry selections have stylar RNases, some of which appear to be similar to the $S$-RNases already cloned from sweet cherry.

Table 1 . Sweet cherry cultivars used as $S_{-}$allele standards and their $S_{-}$ genotypes (Hauck et al., 2001).

\begin{tabular}{lc}
\hline \hline Cultivar & $S_{-}$genotype \\
\hline Early Rivers & $S^{1} S^{2}$ \\
Bing & $S^{3} S^{4}$ \\
Gaucher, Hedelfingen & $S^{3} S^{5}$ \\
Gold & $S^{3} S^{6}$ \\
Charger & $S^{1} S^{7}$ \\
Guigne d'Annonay & $S^{2} S^{7}$ \\
Burlat, Mona & $S^{3} S^{9}$ \\
Inge & $S^{4} S^{9}$ \\
Orleans 171 & $S^{10} S^{11}$ \\
Schneiders & $S^{3} S^{12}$ \\
\hline
\end{tabular}




\section{Materials and Methods}

Plant material. Thirteen sour cherry selections growing at the Michigan State University Clarksville Horticultural Experiment Station, Clarksville, Mich., were used for this research: 'Cigany 59', 'Crisana', 'ErdiBotermo', 'Erdi Nagygyumolcsu' , 'Favorit', 'Montmorency', 'Pandy 38', 'Pandy 114', 'Rheinische Schattenmorelle', 'Surefire', 'Tschernokorka', 'Ujfehertoi Furtos', and MSU seedling selection I 20 (36). Twelve sweet cherry cultivars were used to provide standards for the previously reported $S$-alleles, $S^{1}, S^{7}, S^{9}$, $S^{12}$ (Table 1). Leaves of 'Bing', 'Hedelfingen', and 'Gold' were collected from the Michigan State University North West Horticultural Research Station, Traverse City, Mich. Leaves of 'Early Rivers' and 'Burlat' were kindly provided by J. Soejima (Morioka, Japan) and leaves of 'Charger', 'Gaucher', 'Inge', and 'Orleans 171 ' were kindly provided by K. Tobutt (East Malling, United Kingdom) and leaves of 'Guigne d' Annonay', 'Schneiders', were kindly provided by C. Choi and R. L. Andersen (Geneva, N.Y.). Leaves of 'Mona' were obtained from the USDA National Clonal Repository, Davis, Calif. The leaf material was prepared for DNA isolation as described by Hauck et al. (2001).

Pollen tube Growth assays. Pollination tests were performed based on Lansari and Iezzoni (1990) but with substantial modifications. Pollen from newly opened flowers was collected from both the cultivars being tested (self pollen) and from a bulk consisting of several cultivars (outcross pollen). Ten emasculated flowers were hand pollinated when receptive $(24 \mathrm{~h}$ after emasculation) with self-pollen in the lab $\left(25^{\circ} \mathrm{C}\right)$. The other 10 flowers were pollinated with outcross pollen in the lab $\left(25^{\circ} \mathrm{C}\right)$. The outcross and self-pollinated pistils were collected $72 \mathrm{~h}$ after pollination and immersed in fixing solution [ 1 chloroform : 3 (95\%) ethanol : 1 glacial acetic acid) (v/v)] for $24 \mathrm{~h}$, transferred to $100 \%$ ethanol, and stored at $4{ }^{\circ} \mathrm{C}$ until used. The pistils were washed thoroughly under running tap water and incubated in 10 $\mathrm{N} \mathrm{NaOH}$ for 5 to $6 \mathrm{~h}$ to soften the tissues. The pistils were then soaked in $0.1 \%$ aniline blue solution with $33 \mathrm{~mm} \mathrm{~K}_{3} \mathrm{PO}_{4}$ for $1 \mathrm{~h}$. Pollen tubes were observed by ultraviolet fluorescent microscopy (BX60; Olympus, Tokyo, Japan).

Protein assay. Styles with stigmas were dissected from flower buds of 11 sour cherry selections at the balloon stage of development, frozen immediately in liquid nitrogen, and lyophilized. Acetone powder was prepared from the lyophilized samples as described previously (Tao et al., 1997) and used for protein assay. Crude extracts from the acetone powder were subjected to two-dimensional polyacrylamide gel electrophoresis (2D-PAGE) using nonequilibrium $\mathrm{pH}$ gradient electrophoresis (NEPHGE) in the first dimension and sodium dodecyl sulfate (SDS)-PAGE in the second dimension (Tao et al., 1997). After electrophoresis, proteins in the gel were detected by silver staining using Sil-Best Stain for Protein/PAGE (Nacalai tesque, Kyoto, Japan).

For 'Rheinische Schattenmorelle' and 'Erdi Botermo', the proteins separated by 2D-PAGE were electroblotted onto a polyvinilidene difluoride (PVDF) membrane as described previously (Tao et al., 1997) and glycoproteins were detected with biotin-conjugated concanavalin A (Con A) and horseradish peroxidase-conjugated streptavidin. Peroxidase activity on the membrane was visualized using 4-chloro-1-naphthol. Immunodetection of proteins electroblotted onto PVDF membrane was also conducted for 'Rheinische Schattenmorelle' and 'Erdi Botermo' using the rabbit anti- $S^{c}$-serum prepared against recombinant $S^{c}$ RNase of almond (Ushijima et al., 2001). In addition, for 'Erdi
Botermo', after the proteins were blotted onto the PVDF membrane and detected by Coomassie Blue staining, the portion of the PVDF membrane carrying the proteins of interest was cut out and used. This sample was divided further into two portions, one containing a higher molecular weight protein and one containing a lower molecular weight protein. The N-terminal amino acid sequence of each protein was determined using a gas-phase protein sequencer (476A, Applied Biosystems, Tokyo, Japan) as described by Tao et al. (1997).

CDNA LIBRARY CONSTRUCTION AND SCREENING. Total RNA was isolated from 'Erdi Botermo' styles with stigmas at the balloon stage of development as described by Tao et al. (1999b). Doublestranded cDNA was synthesized from the poly $(\mathrm{A})^{+} \mathrm{RNA}$ isolated from the total RNA, cloned into LambdaZAPII vector (Stratagene, La Jolla, Calif.), and packaged in vitro using MaxPlax Packaging Extract Kit (Epicentre Technologies, Madison, Wis.) as described by Tao et al. (1999b).

One microgram of total RNA from 'Erdi Botermo' was used for first strand cDNA synthesis by SUPER SCRIPT II RT (Life Technologies, Tokyo, Japan) with an Adp-dT primer (5'CGACGTTGTAAAACGACGGCCAGTTTTTTTTTTTTTTTT$\left.3^{\prime}\right)$ that consisted of M13-20 sequence primer and oligo $(\mathrm{dT})_{16}$ (Tao et al., 1999b). Pru-T2 primer (5'-TSTTSTTGSTTTTGCTTTCTTC-3') (Tao et al., 1999b) derived from the cDNA sequence corresponding to the signal peptide sequence of $S$-RNases of sweet cherry was used in 3' rapid amplification of cDNA ends (3' RACE) with M13-20 primer as the adapter primer. Polymerase chain reaction (PCR) condition was identical to that used by Tao et al. (1999b). The PCR products were subcloned into the T-A cloning vector (pGEM-T Easy Vector System; Promega, Madison, Wis.). DNA sequences of the inserts of several clones were determined using the Dye Terminator Cycle Sequencing Kit (Applied Biosystems, Tokyo, Japan) and the ABI PRISM ${ }^{\text {тм }} 310$ Genetic Analyzer (Applied Biosystems, Tokyo, Japan).

Putative 3'RACE clones for $S$-RNases obtained as described above were PCR amplified by Pru-C2 (5'-CTATGGCCAAGTAATTATTCAAACC-3') and Pru-C4R (5'-GGATGTGGTACGATTGAAGCG-3') primers (Tao et al., 1999b). PCR products obtained were labeled by random primer incorporation of DIG-dUTP (Boehringer Mannheim, Tokyo, Japan) and used as probes to screen the primary cDNA library consisting of $1 \times 10^{6}$ plaque forming units. The cDNA library was screened as described by Tao et al. (1999b), selected clones were converted to pBluescript plasmids, and DNA was sequenced as described above. The deduced amino acid sequences of two kinds of cDNAs obtained in this study and sweet cherry $S^{4}$-RNase were aligned using Clustal X (Thompson et al., 1997).
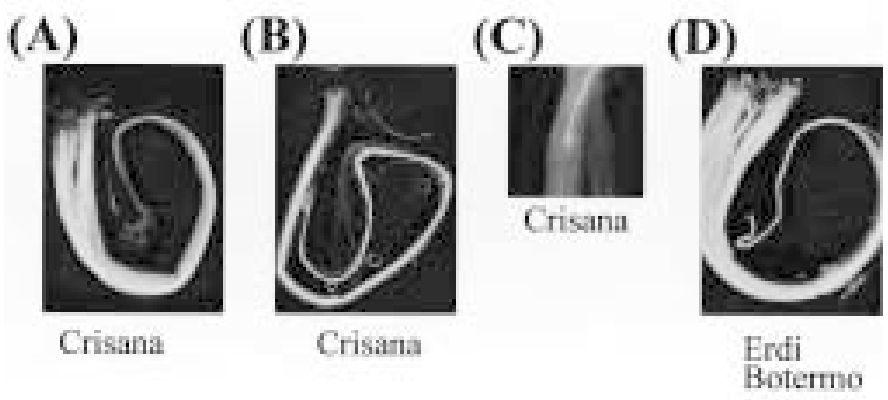

Fig. 1. Pollen tube growth in sour cherry pistils. The pistils were purposely curved before the photographs were taken. (A) Self-pollinated style of the selfincompatible selection, 'Crisana'. (B) Out-cross styles of 'Crisana'. (C) Swelling of the pollen tube tip in self-pollinated pistil of 'Crisana'. (D) Self-pollinated styles of the self-compatible selection, 'Erdi Botermo' 

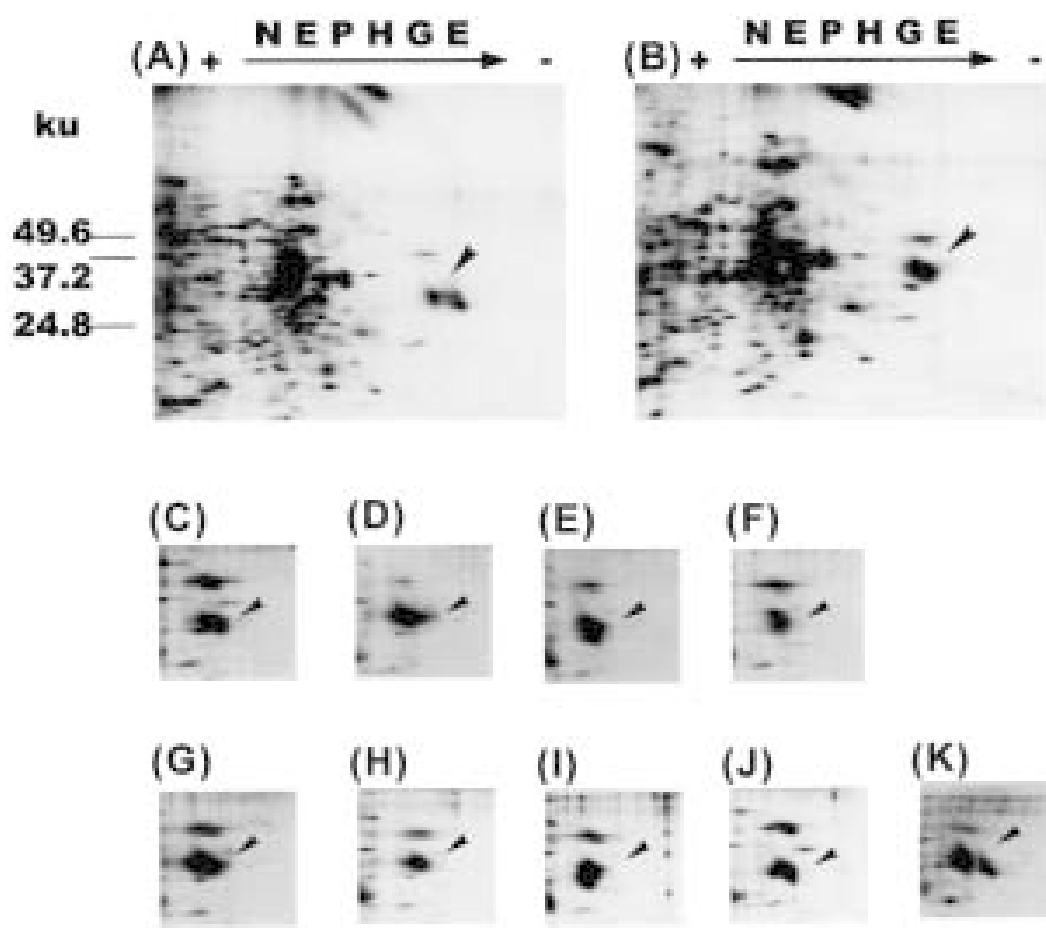

Fig. 2. Identification of $S$-RNases of 11 sour cherry selections. (A-F) stylar proteins from six self-compatible selections and $(\mathbf{G}-\mathbf{K})$ five self-incompatible selections were separated by 2D-PAGE and detected by silver staining. $S$ RNase spots are marked with arrows. ( $\mathrm{u}=$ unified atomic mass unit). (A) 'Rheinische Schattenmorelle', (B) 'Erdi Botermo', (C) 'Montmorency', (D) 'Ujfehertoi Furtos', (E) 'Favorit', (F) 'Surefire', (G) 'Pandy 114', (H) 'Crisana', (I) 'Erdi Nagygyumolcsu', (J) 'Tschernokorka', and (K) MSU seedling selection I 20 (36).

Genomic dNA BLOT ANALYSIS. Total DNA was isolated from young leaves by the hexadecyltrimethylammonium bromide (CTAB) method described by Stockinger et al. (1996). Genomic DNA blot analysis was performed as described by Hauck et al. (2001). Probe cDNAs were prepared from PCR-amplified fragments of the $S^{4}$ - and $S^{6}$-RNase cDNAs from sweet cherry and radiolabelled with ${ }^{32} \mathrm{P}-\mathrm{dCTP}$ as described by Hauck et al. (2001).

PCr Amplification, Cloning, AND dNA SEQuencing OF PCRAMPLIFIED FRAGMENTS OF THE $\boldsymbol{S}$-RNASE FRAGMENTS. As described above for the genomic DNA blot analysis, total DNA was isolated from 11 sour cherry selections and used as template DNA for PCR. PCR procedures were identical to those used by Tao et al. (1999b). PCE-R primer (5'-TGTTTGTTCCATTCGCYTTCCC3'), which corresponds to the previously identified C3 conserved domain of rosaceous $S$-RNases (Ushijima et al., 1998), was designed based on the nucleotide sequences of obtained sour cherry $S$-RNase cDNAs. After PCR with Pru-C2 (Tao et al., 1999 b) and PCE-R primer, the PCR mixture was run on $1.5 \%$ agarose gel and the DNA bands were visualized by ethidium bromide staining. Furthermore, PCR products from 'Erdi Botermo' were subcloned into the T-A cloning vector (pGEM-T Easy Vector System; Promega, Madison, Wis.) and their sequences were determined as described above.

\section{Results and Discussion}

EVALUATION OF SELF-INCOMPATIBILITY OR SELF-COMPATIBILITY IN SOUR CHERRY SELECTIONS. Six selections, 'Erdi Nagygyumolcsu', 'Crisana', 'Pandy 38', 'Pandy 114', 'Tschernokorka' and MSU seedling selection I 20 (36), were SI and no selfpollen tubes reached the ovule $72 \mathrm{~h}$ after pollination in any of the 10 pistils observed (Fig. 1A), while outcross pollen tubes reached the ovule (Fig. 1B). Self-pollen tube growth of these selections was inhibited in the middle part of stylar tissue (Fig. 1A), and swelling of pollen tube tips, which is a typical reaction of gametophytic SI, was observed in the SI sour cherry selections (Fig. 1C). Seven selections, 'Cigany 59', 'Erdi Botermo', 'Montmorency', 'Favorit', 'Rheinische Schattenmorelle', 'Surefire', and 'Ujfehertoi Furtos' were SC because self-pollen tubes successfully reached the ovule (Fig. 1D). These results were consistent with previous observations (Iezzoni, 1996; Lansari and Iezzoni, 1990; Redalen, 1984a, 1984b).

Protein assay. After 2D-PAGE and silver staining of stylar extracts from six SC selections ('Erdi Botermo', 'Montmorency', 'Favorit', 'Rheinische Schattenmorelle', 'Surefire', and 'Ujfehertoi Furtos') and five SI selections ('Erdi Nagygyumolcsu', 'Crisana', 'Pandy 114', 'Tschernokorka', and MSU seedling selection I 20 (36)), protein spots were detected (Fig. 2), that had similar molecular weights and isoelectric points to those of other $S$-RNases in other SI Prunus sp., such as almond (Tao et al., 1997), sweet cherry (Tao et al., 1999b) and Japanese plum (Yamane et al., 1999). Furthermore, for 'Rheinische Schattenmorelle' and 'Erdi Botermo', these stylar proteins were shown to be glycoproteins that contained sugar chains reacting with Con A (Fig. 3A) and exhibited an immunoreaction with anti $S^{c}$-serum raised against $S^{c}$ RNase of almond (Fig. 3B). This result indicates that they are immunologically similar to $S$-RNases of other Prunus sp. The putative $S$-RNase spot from 'Erdi Botermo' was divided into two regions of higher (spot $\mathrm{EB}_{\mathrm{H}}$ ) and lower (spot $\mathrm{EB}_{\mathrm{L}}$ ) molecular weight. The N-terminal amino acid sequences of these proteins were homologous to those of $S$-RNases of other Prunus sp. (Fig. 4) (Tao et al., 1997, 1999b; Yamane et al., 1999).

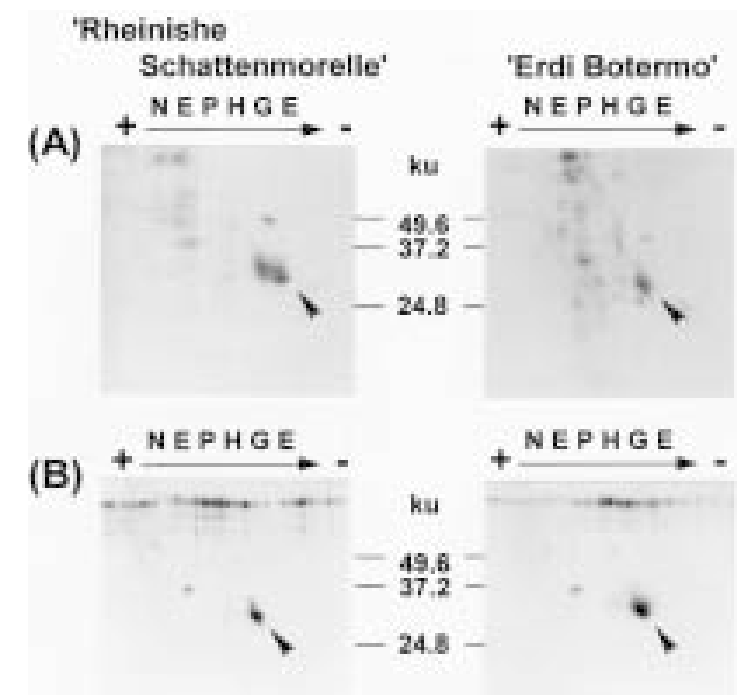

Fig. 3. S-RNase proteins from 'Rheinische Schattenmorelle' and 'Erdi Botermo'. Proteins in the 2D-PAGE gel were blotted to a PVDF membrane and (A) detected by glycoprotein staining with Con $\mathrm{A}$ and $(\mathbf{B})$ immunodetection with the anti- $S^{c}$-serum prepared from almond $S^{c}$-RNase ( $\mathrm{u}=$ unified atomic mass unit). $S$-RNase spots are marked with arrows. 


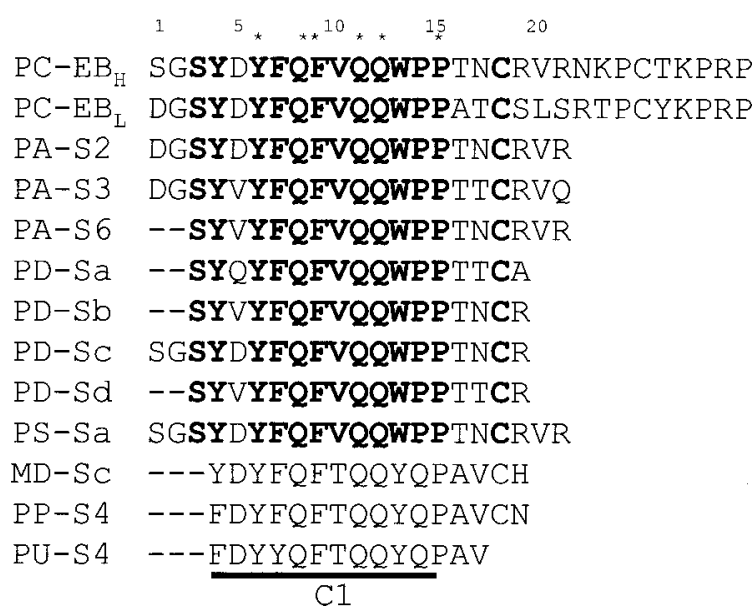

Fig. 4. Alignment of N-terminal amino acid sequences of $S$-RNases of sour cherry 'Erdi Botermo' and other rosaceous $S$-RNases. Amino acid sequences corresponding to the $\mathrm{C} 1$, a previously reported conserved domain of $S$-RNases in Rosaceae (Ishimizu et al., 1998; Ushijima et al., 1998), are indicated at the bottom. Amino acid residues conserved in all Prunus $S$-RNases are indicated by bold face and those conserved in all rosaceous $S$-RNases are marked with asterisks. Sequence data for the $S$-RNases included are as follows: $\mathrm{PC}_{-\mathrm{EB}_{\mathrm{H}}, \mathrm{L}}$ [corresponding to the spot $\mathrm{EB}_{\mathrm{H}}$ and $\mathrm{EB}_{\mathrm{L}}$, respectively, from Prunus cerasus ('Erdi Botermo' sour cherry) (this study)]; PA-S2, S3, and S6 $\left[S^{2}, S^{3}\right.$, and $S^{6}$-RNases of $P$. avium (sweet cherry) (Tao et al., 1999b)]; PD-Sa, Sb, Sc, and Sd [ $S^{a}, S^{b}, S^{c}$, and $S^{d}$-RNases of $P$. dulcis (almond) (Tamura et al., 2000; Ushijima et al., 1998)]; PS-Sa [S ${ }^{a}$-RNase of P. salicina (Japanese plum) (Yamane et al., 1999)]; MD-Sc [S $S^{c}$-RNase of Malus sylvestris var. domestica (apple) (Sassa et al., 1996)]; PP-S4 [S4-RNase of Pyrus pyrifolia (Japanese pear) (Sassa et al., 1996)]; PU-S4 [S4-RNase of Pyrus ussuriensis (Chinese pear) (Tomimoto et al., 1996)].

cDNA CLONING. For 3'RACE using the Pru-T2 primer corresponding to the signal peptide sequence of $S$-RNases of sweet cherry, 10 clones that could be nested PCR-amplified by the AS 1 (5'-TATTTTCAATTTGTNCAGCAATGG-3') and Pru-C4R primer set that were designed based on conserved regions of $S$ RNases of Prunus (Tao et al., 1999b), were obtained. Nine clones had the same nucleotide sequence and their deduced amino acid sequence contained the $\mathrm{N}$-terminal amino acid sequence of the spot $\mathrm{EB}_{\mathrm{H}}$ from 'Erdi Botermo' (Fig. 4). The remaining one clone contained the N-terminal amino acid sequence encoding the spot $\mathrm{EB}_{\mathrm{L}}$ from 'Erdi Botermo' (Fig. 4). These two 3'RACEclones were further PCR amplified by Pru-C2 and Pru-C4R primers and used as probes to screen the cDNA library. About 5000 plaques were screened, and several positive plaques were converted to pBluescript and DNA sequenced. Two different kinds of full-length cDNA clones corresponding to two spots, $\mathrm{EB}_{\mathrm{H}}$ and $\mathrm{EB}_{\mathrm{L}}$, were obtained. The coding region of one cDNA clone encoding the spot $\mathrm{EB}_{\mathrm{H}}$ was exactly the same as the $S^{4}$-cDNA of sweet cherry (Fig. 5) (Tao et al., 1999a). The other cDNA clone encoding the spot $\mathrm{EB}_{\mathrm{L}}$ contained five conserved regions in rosaceous $S$-RNases (Ushijima et al., 1998) but did not share the same DNA sequence with any of known $S$-RNase sequences, suggesting that it encodes a novel $S$-RNase (named $S^{a}$ RNase in this study) in sour cherry (Fig. 5).

$S$-RNASE ALLELES IN TWELVE SOUR CHERRY SELECTIONS. Hybridization signals with the cDNA probes encoding $S^{4}$-, and $S^{6}$-RNases of sweet cherry were observed with all 12 sour cherry selections tested (Fig. 6). With HindIII and XbaI digestions, four different $S$-alleles seemed to be present in three selections, 'Cigany 59', 'Erdi Nagygyumolcsu', and 'Rheinische Schattenmorelle', and three different $S$-alleles were present in all other selections (Table 2; Fig. 6). Three selections, 'Crisana', 'Pandy 38', and 'Pandy 114 ', yielded the same banding pattern for both blots, which is consistent with the fact that 'Crisana' and 'Pandy' represent selections from the same landrace (Iezzoni, 1996).

Based on the RFLP analysis, 'Erdi Botermo' appears to have three different $S$-alleles: $S^{4}, S^{a}$, and $S^{6}$ (Table 2; Fig. 6). In the XbaI digest, 'Erdi Botermo' exhibited the fragment that corresponds to the sweet cherry $S^{6}$-allele, however, the fragment identified from the $H$ indIII digest showed different size from that of the sweet cherry $S^{6}$ allele. To resolve this discrepancy, the 'Erdi Botermo' fragment that was associated with the $S^{6}$-allele was amplified by PCR (Fig. 7) and sequenced. Sequencing data showed this fragment contained a partial DNA sequence unique to the $S^{6}$-RNase gene (data not presented). Therefore, we propose that 'Erdi Botermo' has a $S^{6}$ allele that has an altered HindIII cut site. The mutation might affect transcription of the allele as cDNA encoding $S^{6}$-RNase could not be obtained by screening of the stylar cDNA library or 3'RACE from the mRNA from the style of 'Erdi Botermo'. This conclusion is also indicated by the fact that the protein spot corresponding to $S^{6}$-RNase was absent in the 2D-PAGE profile of 'Erdi Botermo'.

The band corresponding to the $S^{1}$-allele of sweet cherry was found in four SI selections, 'Erdi Nagygyumolcsu', 'Crisana', 'Pandy 38', and 'Pandy 114'. The band corresponding to the $S^{4}$ ' allele was found in three SC selections ('Erdi Botermo', 'Sure-

Fig. 5. Amino acid sequence alignment of two $S$-RNases, $\mathrm{EB}_{\mathrm{L}}$ and $\mathrm{EB}_{\mathrm{H}}$, from 'Erdi Botermo' sour cherry and sweet cherry $S^{4}$-RNase. The alignment was generated by CLUSTAL X (Thompson et al., 1997). Gaps are marked by dashes. The five conserved regions, C1, C2, C3, RC4, and C5 (Ushijima et al., 1998) are shown and boxed, and hypervariable region, RHV (Ushijima et al., 1998), reported in rosaceous $S$-RNases are shown under the alignment and underlined. Sequence data for the $S$-RNases included are as follows: $\mathrm{PC}_{\mathrm{E}} \mathrm{EB}_{\mathrm{L}}, \mathrm{EB}_{\mathrm{H}}$ [corresponding to the spot $\mathrm{EB}_{\mathrm{L}}$ and $\mathrm{EB}_{\mathrm{H}}$, respectively, from Prunus cerasus ('Erdi Botermo' sour cherry) (this study)], PA-S4 [S ${ }^{4}$-RNase of P. avium (sweet cherry) (Tao et al., 1999a)].

\begin{abstract}
PC-EB ${ }_{L} \quad 1$ MVTLKSSLAFLVLAFALFLCFIMSTGDGS YDYFQEVQQWPPATCSLSRTP 50 PC-EB 1 MAIIKSTIAFIVIAAFAFICYVMSSG--SYDYFOFVOOWP PTNCRVRNKP PA-S 4 I MAILKSTLAFLVLAFAFFICYVMSSG--SYDYFQFVQQWPE TNCRVRNKP 50 C1

$\mathrm{PC}-\mathrm{EB}_{\mathrm{L}}$ $\mathrm{PC}-\mathrm{EB}_{\mathrm{H}}$ $\mathrm{PA}-\mathrm{S} 4$

51 CYKPRPPQIFTIHGLWPSNYSNPKRPSNCRGSLFDSRKVYPQLRLNLKIS 100 51 CTKPRPLQNFTIHGLWPSNYSNPRMPSKCTGSLFNFRKVYPQLRSDLKIS 100 51 CTKPRPLQNFTIHGLWPSNYSNPRMPSKCTGSLFNERKVYPQLRSDLKIS 100 C2
\end{abstract}

$\mathrm{PC}-\mathrm{EB}$ $\mathrm{PC}-\mathrm{EB}_{\mathrm{H}}$ $\mathrm{PA}-\mathrm{S} 4$

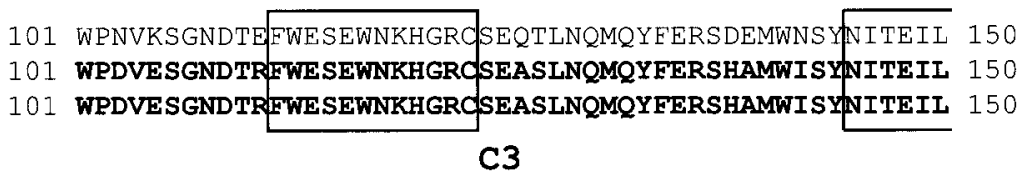

PC-EB 151 KKAQIVPNATRTWKYSDILSPIKAATNTTPILRCKPDPAQSKSQPSQPKS 200 $\mathrm{PC}-\mathrm{EB}_{\mathrm{H}} \quad 151$ KNASIVPSATKNWTYSDIVSPIKRATKRTPLLRCKYDKS----------- 200 PA-S4 151 KNASIVPSATKNWTYSDIVSPIKRATKRTPLLRCKYDKS----------- 200 RC4

PC-EB 201 PQK PQLLHEVVECYDYHAKKQIDCNRT-GCLN-KDISFQ

$P C-E_{H} \quad 201 \quad--$ TQLLHEVVFCYEYDALKQIDCNGTAGCPNQKVISFQ

PA-S4 $201--$ TQLLHEVVFCYEYDALKQIDCNGTAGCPNQKVISFQ C5
239

239

239 


\section{A. Hindlll digest}
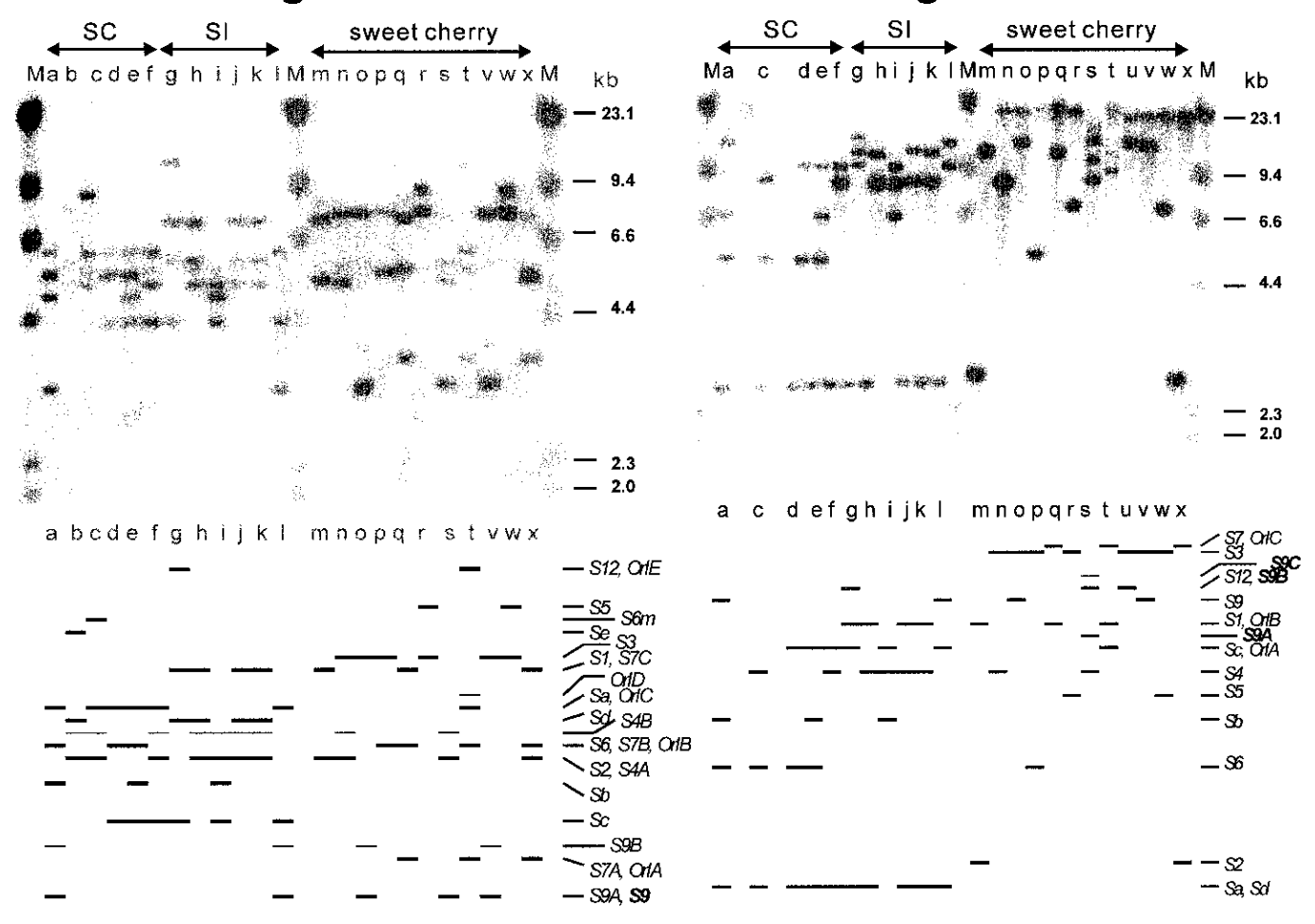

\section{B. Xbal digest}

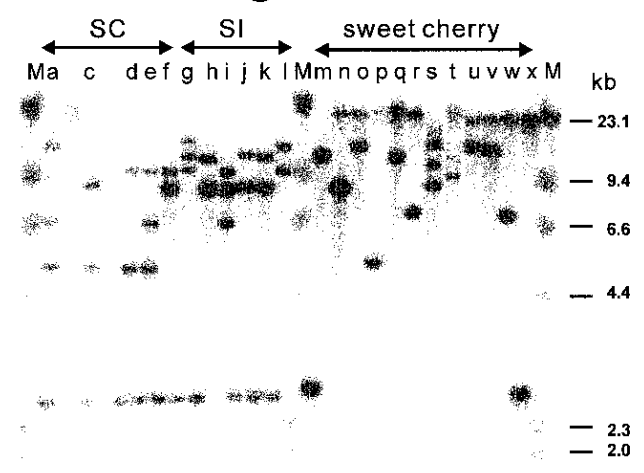

a c defghijkl mnopqrstuvwx

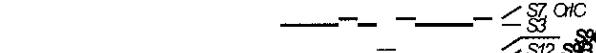

$-S a$

numerical designations, because they have yet to be confirmed to act as SI alleles through crossing studies. PCR amplification of the sour cherry $S$-alleles was consistent with the RFLP analysis (Fig. 7). Recently, at least 14 $S$-alleles, $S^{1}$ - to $S^{7}$-, $S^{9}$ - to $S^{13}$-, and two new putative $S$-alleles, both found in 'NY1625', have been confirmed (Hauck et al., 2001). Although the five novel $S$-alleles, $S^{a}$ - to $S^{e}$-, identified in this study were different from the sweet cherry $S^{l}$ - to $S^{7}$-, $S^{9}$ - to $S^{12}$-alleles, it is possible that these novel $S$-alleles are present in other sweet cherry clones.

The ultimate goal of this research is to determine genetic control of SI/SC in tetraploid sour cherry. Lewis (1947) proposed that heterogenic pollen loses its SI phenotype, which causes breakdown of SI in polyploid plants with diploid relatives possessing a gametophytic SI system. To date, some observations that are consistent with

Fig. 6. Genomic DNA blot analysis of 12 sour cherry selections. Six micrograms of genomic DNA were digested by (A) HindIII or (B) XbaI and hybridized to the cDNAs encoding (A) $S^{6}$-RNase or (B) $S^{4}$-RNase, respectively. M: Lambda/ HindIII marker. (a) 'Cigany 59', (b) 'Ujfehertoi Furtos', (c) 'Erdi Botermo’, (d) 'Montmorency', (e) 'Rheinische Schattenmorelle', (f) 'Surefire', (g) 'Erdi Nagygyumolcsu', (h) 'Crisana', (i) MSU seedling selection I 20 (36), (j) 'Pandy 38', (k) 'Pandy 114', (I) 'Tschernokorka', (m) 'Early Rivers' $\left(S^{l} S^{2}\right)$, (n) 'Bing' $\left(S^{3} S^{4}\right),(\mathbf{o})$ 'Burlat' $\left(S^{3} S^{9}\right),(\mathbf{p})$ 'Gold' $\left(S^{3} S^{6}\right),(\mathbf{q})$ 'Charger' $\left(S^{1} S^{7}\right),(\mathbf{r})$ 'Gaucher' $\left(S^{3} S^{5}\right)$, (s) 'Inge' $\left(S^{4} S^{9}\right)$, (t) 'Orleans 171' $\left(S^{10} S^{11}\right)$, (u) 'Schneiders' $\left(S^{3} S^{12}\right)$, (v) 'Mona' $\left(S^{3} S^{9}\right),(\mathbf{w})$ 'Hedelfingen' $\left(S^{3} S^{5}\right)$, and $(\mathbf{x})$ 'Guigne d'Annonay' $\left(S^{2} S^{7}\right)$. Orl represents $S^{10}$ and $S^{11}$ found in 'Orleans 171'. If more than one fragment corresponds to an allele, $\mathrm{A}$ is used to designate the smallest fragment, $\mathrm{B}$ the next smallest, etc. The fragments corresponding to the $S^{9}$-allele from 'Inge' are bold, whereas the fragments corresponding to the $S^{9}$-allele from 'Burlat' are not bold.

fire', and 'Ujfehertoi Furtos') and in four SI selections ('Crisana', 'Pandy 38', 'Pandy 114', and MSU seedling selection I 20 (36)) (Table 2; Fig. 6). Similarly, four SC selections ('Cigany 59', 'Erdi Botermo', 'Montmorency', and 'Rheinische Schattenmorelle') were shown to have the $S^{6}$-allele of sweet cherry. One SC selection ('Cigany 59') and one SI selection ('Tschernokorka') were shown to have the $S^{9}$-allele of the sweet cherry cultivars 'Burlat' and 'Mona' (Tables 1 and 2; Fig. 6). 'Erdi Nagygyumolcsu' exhibited the band corresponding to the $S^{12}$ allele of the sweet cherry cultivar 'Schneiders' (Tables 1 and 2; Fig. 6).

Five SC selections ('Cigany 59', 'Erdi Botermo', 'Montmorency', 'Rheinische Schattenmorelle', and 'Surefire') and one SI selection ('Tschernokorka') yielded the band that was considered to encode the novel putative $S$-RNase from 'Erdi Botermo', named $S^{a}$-RNase in this study (Table 2; Fig. 6). The other four novel putative $S$-alleles, named $S^{b}-, S^{c}-, S^{d}$-, and $S^{e}$-alleles of sour cherry, were observed in several selections (Table 2, Fig. 6). These putative $S$-alleles were assigned a letter, as opposed to this hypothesis have been obtained. As demonstrated in a tissue culture-derived Lycoper-sicon peruvianum Mill. selection, when an $S^{1} S^{1} S^{2} S^{2}$ individual was self-pollinated, only $S^{1} S^{2}$ pollen achieved fertilization (Chawla et al., 1997). In artificially induced tetraploid lines of Petunia $\times$ hybrida Hort. Vilm.-Andr., the obtained $S^{B 1} S^{B 1} S^{B 1} S^{B 1}$ homoallelic tetraploid remained self-incompatible, whereas the $S^{B 1} S^{B 1} S^{B 2} S^{B 2}$ heteroallelic tetraploid became self-compatible (Entani et al., 1999). In addition, Golz et al. (1999) found breakdown of SI in mutated diploid plants with an extra $S$-allele generated by irradiation. The hypothesis of Lewis (1947) and the observations of Chawla et al. (1997), Entani et al. (1999), and Golz et al. (1999) indicate that tetraploid plants with more than two $S$-alleles are SC, and SI is found only when all of the four $S$-alleles are the same. In this study, however, we identified three or four different $S$-alleles in each SI sour cherry selection. If these $S$-alleles are functional in both pollen and stylar parts, it appears that our results are inconsistent with the hypothesis of Lewis (1947). It is possible that SI/SC in sour cherry is controlled by not only $S$-alleles but also other factors, such as the HT-protein of Nicotiana sp. (McClure et al., 1999). Alternatively, it is possible that the identified $S$-alleles could be mutated such that $S$-proteins of pollen part and/or stylar part are nonfunctional. The genetic control of SI/SC in naturally occurring tetraploid sour cherry is apparently more complicated than that in artificially produced tetraploid tomato(Lycopersicon peruvianum) (Chawla et al., 1997) and petunia (Entani et al.,1999).

In conclusion, it appears that $S$-RNases including sweet cherry $S$-RNases are present in the styles of each SI or SC sour cherry selections. A project to determine genetic control of SI/ SC in tetraploid sour cherry is currently underway, utilizing a sour cherry cross, 'Rheinische Schattenmorelle' x 'Erdi Botermo', in which the progeny are segregating for SI. 
Table 2. Putative $S_{-}$alleles of 12 sour cherry selections predicted by their RFLP kb size on Southern blots following HindIII and XbaI digests. $S^{l}$, $S^{4}, S^{6}, S^{9}$, and $S^{12}$ refer to $S$-alleles already identified in sweet cherry (Hauck et al., 2001) while $S^{a}, S^{b}, S^{c}, S^{d}$, and $S^{e}$ are assigned to the novel putative $S$-alleles identified in sour cherry.

\begin{tabular}{|c|c|c|c|c|c|c|c|c|c|c|c|c|c|c|}
\hline \multirow[b]{4}{*}{ Digest } & \multicolumn{8}{|c|}{ Sweet cherry $S$ alleles } & \multicolumn{4}{|c|}{ Novel $S$ alleles } & \multirow{4}{*}{$\begin{array}{c}\text { No. of } \\
S_{-} \text {alleles }\end{array}$} & \multirow{4}{*}{$\begin{array}{l}\text { Identified } \\
S_{-} \text {alleles }\end{array}$} \\
\hline & $\mathrm{S} 1$ & $\mathrm{~S} 4^{\mathrm{z}}$ & $\mathrm{S} 4^{\mathrm{z}} \mathrm{s}$ & $\mathrm{S} 6 \mathrm{~m}^{\mathrm{y}}$ & S6 & $S 9^{x}$ & $S 9^{x}$ & $\mathrm{~S} 12$ & $\mathrm{Sa}$ & $\mathrm{Sb} \quad \mathrm{Sc}$ & $\mathrm{Sd}$ & $\mathrm{Se}$ & & \\
\hline & \multicolumn{8}{|c|}{$\mathrm{kb}$ size } & \multicolumn{4}{|c|}{ kb size } & & \\
\hline & 8.7 & 5.6 & 6.1 & 9 & 5.8 & 3.1 & 4 & 12.1 & 6.4 & 5.14 .6 & 6.2 & 9.6 & & \\
\hline \multicolumn{15}{|l|}{ HindIII } \\
\hline \multicolumn{15}{|l|}{ Self-compatible cultivars } \\
\hline Cigany 59 & & & & & $\mathrm{x}$ & $\mathrm{x}$ & $\mathrm{x}$ & & $\mathrm{x}$ & $\mathrm{x}$ & & & 4 & $\mathrm{~S} 6, \mathrm{~S} 9, \mathrm{Sa}, \mathrm{Sb}$ \\
\hline Ujfehertoi Furtos & & $\mathrm{x}$ & $\mathrm{x}$ & & & & & & & & $\mathrm{x}$ & $\mathrm{x}$ & 3 & $\mathrm{~S} 4, \mathrm{Sd}, \mathrm{Se}$ \\
\hline Erdi Botermo & & $\mathrm{x}$ & $\mathrm{x}$ & $\mathrm{x}$ & & & & & $\mathrm{x}$ & & & & 3 & $\mathrm{~S} 4, \mathrm{~S} 6 \mathrm{~m}, \mathrm{Sa}$ \\
\hline Montmorency & & & & & $\mathrm{x}$ & & & & $\mathrm{x}$ & $\mathrm{x}$ & & & 3 & $\mathrm{~S} 6, \mathrm{Sa}, \mathrm{Sc}$ \\
\hline Rheinische Schattenmorelle & & & & & $\mathrm{x}$ & & & & $\mathrm{x}$ & $\mathrm{x}$ & & & 4 & $\mathrm{~S} 6, \mathrm{Sa}, \mathrm{Sb}, \mathrm{Sc}$ \\
\hline Surefire & & $\mathrm{x}$ & $\mathrm{x}$ & & & & & & $\mathrm{x}$ & $\mathrm{x}$ & & & 3 & $\mathrm{~S} 4, \mathrm{Sa}, \mathrm{Sc}$ \\
\hline \multicolumn{15}{|l|}{ Self-incompatible cultivars } \\
\hline Erdi Nagygyumolcsu & $\mathrm{x}$ & & & & & & & $\mathrm{x}$ & & $\mathrm{x}$ & $\mathrm{x}$ & & 4 & $\mathrm{~S} 1, \mathrm{~S} 12, \mathrm{Sc}, \mathrm{Sd}$ \\
\hline Crisana & $\mathrm{x}$ & $\mathrm{x}$ & $\mathrm{x}$ & & & & & & & & & $\mathrm{x}$ & 3 & $\mathrm{~S} 1, \mathrm{~S} 4, \mathrm{Sd}$ \\
\hline MSU seedling I 20 (36) & & $\mathrm{x}$ & $\mathrm{x}$ & & & & & & & $\mathrm{x}$ & & & 3 & $\mathrm{~S} 4, \mathrm{Sb}, \mathrm{Sc}$ \\
\hline Pandy 38 & $\mathrm{x}$ & $\mathrm{x}$ & $\mathrm{x}$ & & & & & & & & $\mathrm{x}$ & & 3 & $\mathrm{~S} 1, \mathrm{~S} 4, \mathrm{Sd}$ \\
\hline Pandy 114 & $\mathrm{x}$ & $\mathrm{x}$ & $\mathrm{x}$ & & & & & & & & $\mathrm{x}$ & & 3 & $\mathrm{~S} 1, \mathrm{~S} 4, \mathrm{Sd}$ \\
\hline \multirow[t]{4}{*}{ Tschernokorka } & & & & & & $\mathrm{x}$ & $\mathrm{x}$ & & $\mathrm{x}$ & $\mathrm{x}$ & & & 3 & $\mathrm{~S} 9, \mathrm{Sa}, \mathrm{Sc}$ \\
\hline & \multicolumn{7}{|c|}{ Sweet cherry $S_{-}$alleles } & \multicolumn{3}{|c|}{ Novel $S_{-}$alleles } & & & & \\
\hline & $\mathrm{S} 1$ & S4 & $S$ & S6 & S9 & $\mathrm{S} 12$ & & $\mathrm{Sa}, \mathrm{Sd}$ & $\mathrm{Sb}$ & $\mathrm{Sc}$ & & & & \\
\hline & \multicolumn{7}{|c|}{$\mathrm{kb}$ size } & \multicolumn{3}{|c|}{$\mathrm{kb}$ size } & & & No. of & Identified \\
\hline Digest & 13 & 8.8 & & 5.5 & 15 & 16 & & 2.4 & 5 & 9.4 & & & $S_{-}$alleles & $S_{-}$alleles \\
\hline \multicolumn{15}{|l|}{$\overline{X b a \mathrm{I}}$} \\
\hline \multicolumn{15}{|l|}{ Self-compatible cultivars } \\
\hline Cigany 59 & & & & $\mathrm{x}$ & $\mathrm{x}$ & & & $\mathrm{x}$ & $\mathrm{x}$ & & & & 4 & $\mathrm{~S} 6, \mathrm{~S} 9, \mathrm{Sa}, \mathrm{Sb}$ \\
\hline Erdi Botermo & & $\mathrm{x}$ & & $\mathrm{x}$ & & & & $\mathrm{x}$ & & & & & 3 & $\mathrm{~S} 4, \mathrm{~S} 6, \mathrm{Sa}$ \\
\hline Montmorency & & & & $\mathrm{x}$ & & & & $\mathrm{x}$ & & $\mathrm{x}$ & & & 3 & $\mathrm{~S} 6, \mathrm{Sa}, \mathrm{Sc}$ \\
\hline Rheinische Schattenmorelle & & & & $\mathrm{x}$ & & & & $\mathrm{x}$ & $\mathrm{x}$ & $\mathrm{x}$ & & & 4 & $\mathrm{~S} 6, \mathrm{Sa}, \mathrm{Sb}, \mathrm{Sc}$ \\
\hline Surefire & & $\mathrm{x}$ & & & & & & $\mathrm{x}$ & & $\mathrm{x}$ & & & 3 & $\mathrm{~S} 4, \mathrm{Sa}, \mathrm{Sc}$ \\
\hline \multicolumn{15}{|l|}{ Self-incompatible cultivars } \\
\hline Erdi Nagygyumolcsu & $\mathrm{x}$ & & & & & $\mathrm{x}$ & & $\mathrm{x}$ & & $\mathrm{x}$ & & & 4 & $\mathrm{~S} 1, \mathrm{~S} 12, \mathrm{Sc}, \mathrm{Sd}$ \\
\hline Crisana & $\mathrm{x}$ & $\mathrm{x}$ & & & & & & $\mathrm{x}$ & & & & & 3 & $\mathrm{~S} 1, \mathrm{~S} 4, \mathrm{Sd}$ \\
\hline MSU seedling I 20 (36) & & $\mathrm{x}$ & & & & & & & $\mathrm{x}$ & $\mathrm{x}$ & & & 3 & $\mathrm{~S} 4, \mathrm{Sb}, \mathrm{Sc}$ \\
\hline Pandy 38 & $\mathrm{x}$ & $\mathrm{x}$ & & & & & & $\mathrm{x}$ & & & & & 3 & $\mathrm{~S} 1, \mathrm{~S} 4, \mathrm{Sd}$ \\
\hline Pandy 114 & $\mathrm{x}$ & $\mathrm{X}$ & & & & & & $\mathrm{x}$ & & & & & 3 & $\mathrm{~S} 1, \mathrm{~S} 4, \mathrm{Sd}$ \\
\hline Tschernokorka & & & & & $\mathrm{x}$ & & & $\mathrm{x}$ & & $\mathrm{x}$ & & & 3 & $\mathrm{~S} 9, \mathrm{Sa}, \mathrm{Sc}$ \\
\hline
\end{tabular}

$\overline{\mathrm{z}}$ The $\mathrm{S}^{4}$ allele band is identified by two fragments of unequal intensity. The $6.1 \mathrm{~kb}$ band is faint and sometimes not found because of short exposure time as described by Hauck et al. (2001).

y'Erdi Botermo' has a mutated $S^{6}$ allele which has an altered HindIII cut site (see text).

${ }^{x}$ The $S^{9}$ allele band is identified by two fragments of unequal intensity. The 4-kb band is faint and sometimes not found because of short exposure time as described by Hauck et al. (2001).

\section{Literature Cited}

Boskovic, R. and K.R. Tobutt. 1996. Correlation of stylar ribonuclease zymograms with incompatibility alleles in sweet cherry. Euphytica 90:245-250.

Brettin, T.S., R. Karle, E.J. Crowe, and A.F. Iezzoni. 2000. Chloroplast inheritance and DNA variation in sweet, sour, and ground cherry. J. Hered. 91:75-79.

Brewbaker, J.L. 1954. Incompatibility in autotetraploid Trifolium repens 1. Competition and self-compatibility. Genetics 39:307-316.

Broothaerts, W., G.A. Janssens, P. Proost, and W.F. Broekaert. 1995. cDNA cloning and molecular analysis of two self-incompatibility alleles from apple. Plant Mol. Biol. 27:499-511.

Burgos, L., O. Perez-Tornero, J. Ballester, and E. Olmos. 1998. Detection and inheritance of stylar ribonucleases associated with incompat- ibility alleles in apricot. Sexual Plant Reproduction 11:153-158.

Chawla, B., R. Bernatzky, W. Liang, and M. Marcotrigiano. 1997. Breakdown of self-incompatibility in tetraploid Lycopersicon peruvianum: Inheritance and expression of $S$-related proteins. Theor. Appl. Genet. 95:992-996.

Crane, M.B. and D. Lewis. 1942. Genetical studies in pears. III. Incompatibility and sterility. J. Genet. 43:31-42.

de Nettancourt, D. 1977. Incompatibility in angiosperms. Springer, New York.

de Nettancourt, D., F. Saccardo, U. Laneri, and E. Capaccio. 1974. Selfcompatibility in a spontaneous tetraploid of Lycopersicon peruvianum Mill., p. 77-84. In: Polyploidy and induced mutations in plant breeding, Intl. Atomic Energy Agency, Vienna, Austria.

Entani, T., S. Takayama, M. Iwano, H. Shiba, F-S. Che, and A. Isogai. 1999. Relationship between polyploidy and pollen self-incompatibil- 


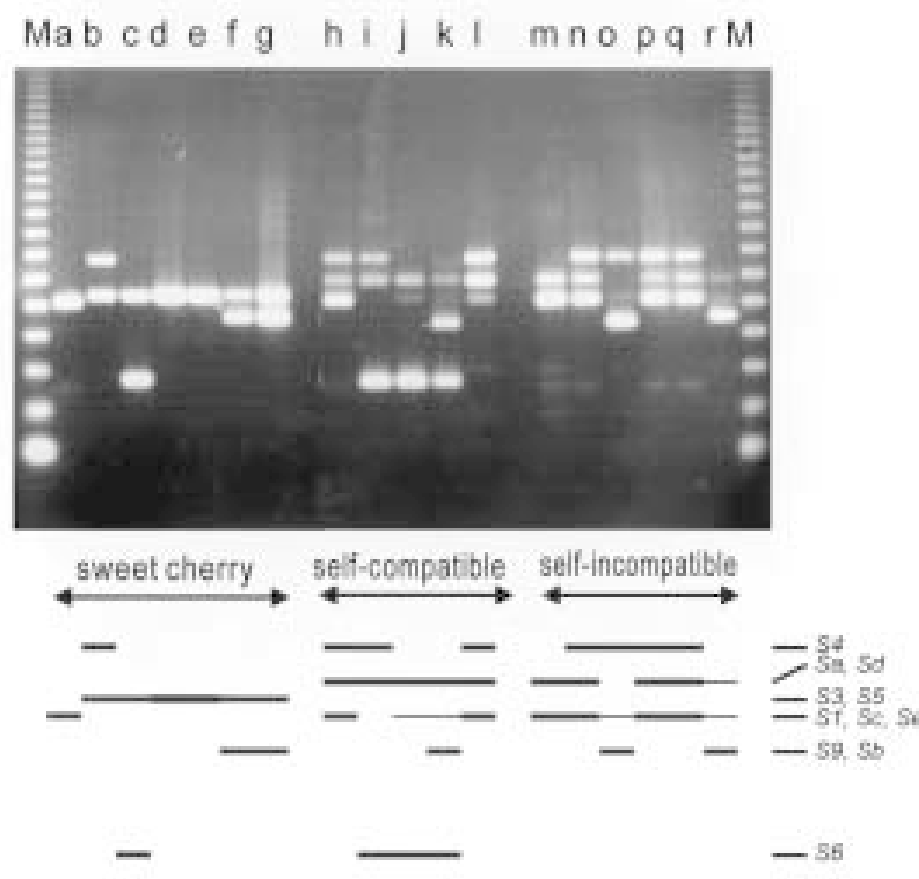

Fig. 7. PCR analysis for $S$-alleles of 11 sour cherry selections. Genomic DNA was PCR amplified with Pru-C2 (Tao et al., 1999b) and PCE-R primer set, separated on an agarose gel and detected with ethidium bromide staining. M: 123 bp DNA ladder. (a) 'Early Rivers' $\left(S^{l} S^{2}\right)$, (b) 'Bing' $\left(S^{3} S^{4}\right)$, (c) 'Gold' $\left(S^{3} S^{6}\right)$, (d) 'Hedelfingen' $\left(S^{3} S^{5}\right)$, (e) 'Gaucher' $\left(S^{3} S^{5}\right)$, (f) 'Burlat' $\left(S^{3} S^{9}\right),(\mathbf{g})$ 'Mona' $\left(S^{3} S^{9}\right)$, (h) 'Ujfehertoi Furtos', (i) 'Erdi Botermo', (j) 'Montmorency', (k) 'Rheinische Schattenmorelle', (l) 'Surefire', (m) 'Erdi Nagygyumolcsu', (n) 'Crisana', (o) MSU seedling selection I 20 (36), (p) 'Pandy 38', (q) 'Pandy 114', and (r) 'Tschernokorka'.

ity phenotype in Petunia hybrida Vilm. Biosci. Biotechnol. Biochem. 63:1882-1888.

Golz, J.F., V. Su, A.E. Clarke, and E. Newbigin. 1999. A molecular description of mutations affecting the pollen component of the Nicotiana alata $S$ locus. Genetics 152:1123-1135.

Hauck, N.R., A.F. Iezzoni, H. Yamane, and R. Tao. 2001. Revisiting the $S$-allele nomenclature in sweet cherry (Prunus avium L.) using RFLP profiles. J. Amer. Soc. Hort. Sci. 127(6):654-660.

Iezzoni, A.F. 1996. Sour cherry cultivars: Objectives and methods of fruit breeding and characteristics of principal commercial cultivars, $p$. 113-126. In: A.D. Webster and N.E. Looney (eds.). Cherries: Crop physiology, production, and uses. CAB Intl., Oxon, United Kingdom.

Ishimizu, T., Y. Sato, T. Saito, Y. Yoshimura, S. Norioka, T. Norioka, and F. Sakiyama. 1996. Identification and partial amino acid sequences of seven $S$-RNases associated with self-incompatibility of Japanese pear, Pyrus pyrifolia Nakai. J. Biochem. 120:326-334.

Ishimizu, T., T. Shinkawa, F. Sakiyama, and S. Norioka. 1998. Primary structural features of rosaceous $S$-RNases associated with gametophytic self-incompatibility. Plant Mol. Biol. 37:931-941.

Lansari, A. and A. Iezzoni. 1990. A preliminary analysis of selfincompatibility in sour cherry. HortScience 25:1636-1638.

Lewis, D. 1947. Competition and dominance of incompatibility alleles in diploid pollen. Heredity 1:85-108.

Livermore, J.R. and R.E. Johnstone. 1940. The effect of chromosome doubling on the crossability of Solanum chacoense, S. jamessi and $S$. bulbocastanum with $S$. tuberosum. Amer. Potato J. 17:170-173.

McClure, B., B. Mou, S. Canevascini, and R. Bernatzky. 1999. A small asparagine-rich protein required for $S$-allele-specific pollen rejection in Nicotiana. Proc. Natl. Acad. Sci. USA 96:13548-13553.

Olden, E.J. and N. Nybom. 1968. On the origin of Prunus cerasus L. Hereditas 59:327-345.

Pandy, K.K. 1968. Colchicine induced changes in the self-incompatibility behavior of Nicotiana. Genetica 39:257-271.

Redalen, G. 1984a. Cross pollination of five sour cherry cultivars. Acta Hort. 149:71-76.

Redalen, G. 1984b. Fertility in sour cherries. Gartenbauwissenschaft 49:212-217.

Sassa, H., H. Hirano, and H. Ikehashi. 1992. Self-incompatibility-related RNases in styles of Japanese pear (Pyrus serotina Rehd.). Plant Cell Physiol. 33:811-814.

Sassa, H., N. Mase, H. Hirano, and H. Ikehashi. 1994. Identification of self-incompatibility-related glycoproteins in styles of apple (Malus $\times$ domestica). Theor. Appl. Genet. 89:201-205.

Sassa, H., T. Nishio, Y. Kowyama, H. Hirano, T. Koba, and H. Ikehashi. 1996. Self-incompatibility $(S)$ alleles of the Rosaceae encode members of a distinct class of the T2/S ribonuclease superfamily. Mol. Gen. Genet. 250:547-557.

Stockinger, E.J., C.A. Mulinix, C.M. Long, T.S. Brettin, and A.F. Iezzoni. 1996. A linkage map of sweet cherry based on RAPD analysis of a microspore-derived callus culture population. J. Hered. 87:214218.

Stout, A.B. and C. Chandler. 1942. Hereditary transmission of induced tetraploidy and compatibility in fertilization. Science 96:257.

Tamura, M., K. Ushijima, H. Sassa, H. Hirano, R. Tao, T.M. Gradziel, and A.M. Dandekar. 2000. Identification of self-incompatibility genotypes of almond by allele specific PCR analysis. Theor. Appl. Genet. 101:344-349.

Tao, R., H. Yamane, H. Sassa, H. Mori, T.M. Gradziel, A.M. Dandekar, and A. Sugiura. 1997. Identification of stylar RNases associated with gametophytic self-incompatibility in almond (Prunus dulcis). Plant Cell Physiol. 38:304-311.

Tao, R., H. Yamane, and A. Sugiura. 1999a. Cloning and nucleotide sequences of cDNAs encoding S1- and S4-RNases (accession nos. AB028153 and AB028154) from sweet cherry (Prunus avium L.) (PGR99-121). Plant Physiol. 120:1207.

Tao, R., H. Yamane, A. Sugiura, H. Murayama, H. Sassa, and H. Mori. 1999 b. Molecular typing of $S$-alleles through identification, characterization and cDNA cloning for $S$-RNases in sweet cherry. J. Amer. Soc. Hort. Sci. 124:224-233.

Thompson, J.D., T.J. Gibson, F. Plewniak, F. Jeanmougin, and D.G. Higgins. 1997. The clustal X windows interface: Flexible strategies for multiple sequence alignment aided by quality analysis tools. Nucleic Acids Res. 25:4876-4882.

Tomimoto, Y., T. Nakazaki, H. Ikehashi, H. Ueno, and R. Hayashi. 1996. Analysis of self-incompatibility-related ribonucleases ( $S$-RNases) in two species of pears, Pyrus communis and P. ussuriensis. Sci. Hort. 66:159-167.

Ushijima, K., H. Sassa, M. Tamura, M. Kusaba, R. Tao, T.M. Gradziel, A.M. Dandekar, and H. Hirano. 2001. Characterization of the $S$ locus region of almond (Prunus dulcis): Analysis of a somaclonal mutant and a cosmid contig for an $S$ allele. Genetics 158:379-386.

Ushijima, K., H. Sassa, R. Tao, H. Yamane, A.M. Dandekar, T.M. Gradziel, and H. Hirano. 1998. Cloning and characterization of cDNAs encoding $S$-RNases in almond (Prunus dulcis): Primary structural features and sequence diversity of the $S$-RNases in Rosaceae. Mol. Gen. Genet. 260:261-268.

Yamane, H., R. Tao, and A. Sugiura. 1999. Identification and cDNA cloning for $S$-RNases in self-incompatible Japanese plum (Prunus salicina Lindl. cv. Sordum). Plant Biotechnol. 16:389-396. 